\title{
FACILITY LAYOUT DESIGN - REVIEW OF CURRENT RESEARCH DIRECTIONS
} pages: $70-79$

\author{
MATEUSZ KIKOLSKI, CHIEN-HO KO
}

\section{A B S T R A C T}

The article discusses the topic of designing the optimal distribution of workstations within a production plant. A review focused on publications on this subject in the Scopus database, covering the years 1975-2017. The article presents a facility layout problem and basic principles of optimisation methods for the distribution of workstations within the factory. The author proposes a methodology for designing the optimal distribution of workstations using available optimisation methods and computer simulation. Also, directions for further research are indicated.

KEY WORDS

facility layout, production lines design, production optimisation, workplace planning

DOI: $10.2478 /$ emj-2018-0018
Corresponding author:

Mateusz Kikolski

Bialystok University of Technology, Faculty of Engineering Management, Poland e-mail:m.kikolski@pb.edu.pl

Chien-Ho Ko

National Pingtung University of Science and Technology, Department of Civil Engineering, Taiwan

e-mail: ko@mail.npust.edu.tw

\section{INTRODUCTION}

Contemporary production companies must quickly adapt to the changing requirements of customers, i.e. implement structural and technological changes and production projects related to manufacturing of new products (Koliński \& Tomkowiak, 2010). The dynamic development of technology, under conditions of globalisation and strong compe- tition, determines the use of new, innovative, efficient and more profitable solutions in the field of production engineering (Halicka, 2016a). The correct division and organisation of the workflow within a given production unit is the basis for the functioning of production processes (Kosieradzka, 2008).

Important factors enabling the improvement of the manufacturing process are the planning of ratio- 
nal material flows in the production process, aimed at reducing production-in-progress stock (Wolniak, 2013), and the correct distribution of production infrastructure inside a plant (Staniewska, 2015). These factors are related to facility layout.

Continuous improvement could be regarded as a principle for an enterprise's survival (Godinho Filho et al., 2016). Improvements can be carried out at any stage of the manufacturing process. From the point of view of a manufacturing company, the productivity of a production line is a key parameter (Brundage et al., 2016). The performance analysis, which assesses the level of production, the average level of stock as well as the profit rate is of great importance in the design and operation of production lines (Gálová et al., 2018). The essence of production line improvement lies in the continuous analysis of carried out processes. Facility layout, elements that make up the production line, plays a crucial role in production improvement.

Determining and defining emerging problems is decisive and allows choosing the best optimisation solution while improving production performance (Kikolski, 2018). Methods for the optimisation of production lines mainly focus on the improvement of line performance or increasing the speed of its operation (Azadivar \& Wang, 2000).

The main factors determining the structure and organisation of production lines are design goals, required or available infrastructure and the number of products manufactured. How to utilise available infrastructure to effectively produce required products has been considered as a goal of facility layout design (Friedrich et al., 2018).

\section{CHARACTERISTICS OF THE FACILITY LAYOUT PROBLEM}

The basic objective of planning the deployment of workstations is to develop a system that would be the most suitable for production and bring savings. Among the types of workstation placement, one can distinguish process-oriented locations such us nesting system - related machines in production sockets, the product such us flow system - machines arranged according to the order of tasks and production lines such us grouping of machines into lines for similar products. Firstly, the main optimisation problem is the location of the devices. The arrangement work- places facing the product have a problem, namely, a proper balancing of the production line (Zwierzyński, 2018). In the case of specialised industries, the appropriate distribution of production departments is also paramount: important departments should be located close to each other and separate those departments that should not be in close proximity (Kikolski, 2018).

One of the key elements of production optimisation is proper planning and scheduling of production tasks and the deployment of workstations. The production efficiency depends largely on the location of the production equipment within the plant. There is also a close relationship between the manufacturing process and the available surface (John \& Jenson, 2013). Appropriate placement of machines within a production line considers the optimal use of available space, time and cost of material flow, and production flexibility. The incorrect layout of workplaces results in possible losses (Piskrzyńska \& Cieślar, 2015). There are many factors affecting the shape and manner particular to the operation of production lines, including the number of working shifts, the size of production batches and their nature (variable or constant size of the lot), and types of transport and storage. Due to a large number of possible connections between positions and the resulting differences in their mutual location, the optimisation problem is usually solved with one (or several, together) criteria (Lis \& Santarek, 1980):

- minimisation of transport or mass of transported details,

- minimisation of transport routes,

- minimisation of the number of transport operations,

- minimising transport costs,

- minimising the costs of locating positions,

- minimisation of total transport costs and location of stands.

The optimal placement of workplaces should shorten the production cycle, reduce production costs or improve the use of production resources $(\mathrm{Hu}$ et al., 2011; Vergara \& Kim, 2009).

\section{LITERATURE REVIEW}

To identify methods used for the optimisation of the workstation distribution, a bibliometric analysis was made, which enabled the assessment of the dynamics of changes in the number of publica- 


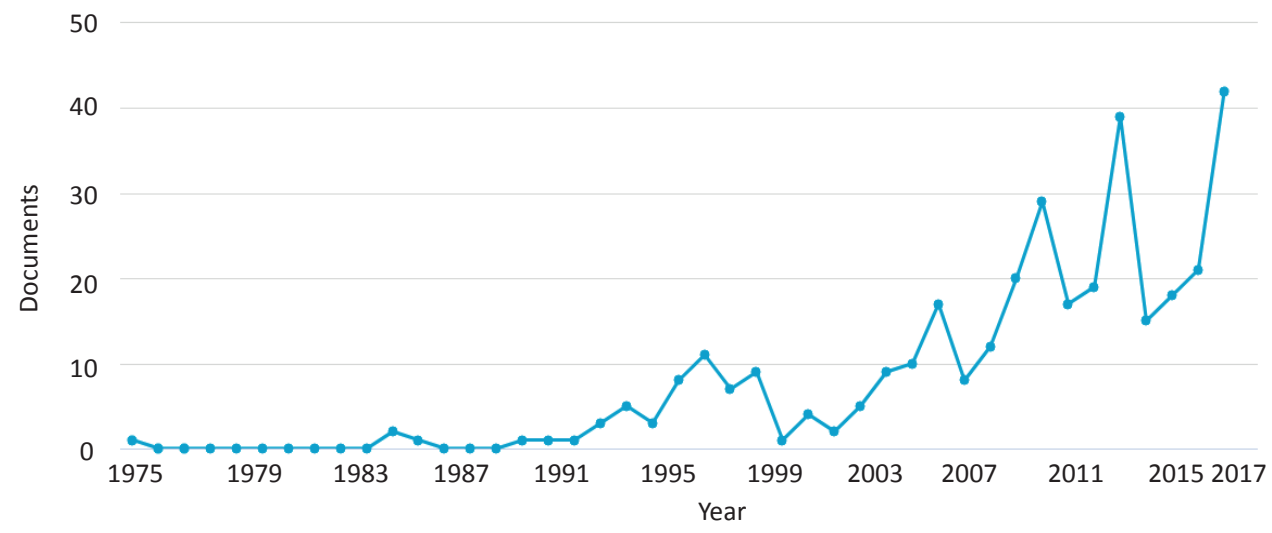

Fig. 1. Number of publications indexed in 1975-2017 in Scopus database referring to the facility layout optimisation

Source: elaborated by the authors based on (http://bazy.pb.edu.pl).

tions in the examined period. Due to the size and availability, the publications were reviewed in the Scopus database. The database search was focused on the problem of facility layout optimisation mentioned in keywords, titles and abstracts. The analysis covered the years 1975-2017. 341 studies were found registered in the Scopus database for the analysed period. The importance of the topic is constantly growing. This statement is supported by the growing number of studies available in Scopus database from one year to another. The number of publications in particular years of the analysed period is shown in Fig. 1.

In the first part of the surveyed period, the increase in the number of publications was slow. The first study available in the database comes from 1975 , but in the next fifteen years, only five articles were published in the field of facility layout optimisation. The last 25 years indicate a sudden increase in the interest in the discussed topic. The number of research works on the problem of workstation distribution optimisation underwent a steady increase. Also, research efforts intensified at the beginning of the second decade of the 21st century, when the number of studies increased threefold in comparison to the period preceding 2010 .

Main thematic areas of the highlighted articles available in the Scopus database were Engineering, Computer Science, Decision Science and Mathematics, amounting to a total of $84,5 \%$ of all publications. The indicated thematic areas include both methods of solving (methods) and presenting (models) problems related to the optimisation of the layout of the production halls.

The final stage of the bibliometric analysis concerned the evaluation of the coexistence of words and their co-classification. The method used to analyse the coexistence of words was based on counting the sequence of words appearing in the text. This method allows the classification of research sub-areas based on the co-occurrence of words. Using the VOSviewer software, a bibliometric map was developed, which is a visualisation of the results received from the analysis of coexisting words. The size of the circles reflects the number of specific words, while the distance between the circles depends on the number of co-occurrences (Halicka, 2016b). The results of the article analysis are presented in Fig. 3.

The analysis of the coexistence of words made it possible to identify five clusters that together contained 41 words/terms. The proposed cluster names refer to most of the terms of a given cluster. The analysis of the coexistence of keywords identified by the authors of articles resulted in the following clusters:

- Cluster I - ways for presenting the layout of workplaces,

- Cluster II - methods of system optimisation,

- Cluster III - factors affecting the distribution of workstations,

- Cluster IV - ways for formulating problems related to the arrangement of objects,

- Cluster V - study objects.

According to the literature review, main problems related to the design and operation of production lines were (Teunter et al., 2008; Zawadzka, 2007) determining the number of machines within a line, the location of inter-operation buffers and their size, and the layout of machines and stations working within a plant. Appropriate optimisation methods are necessary for the elimination of the problems men- 


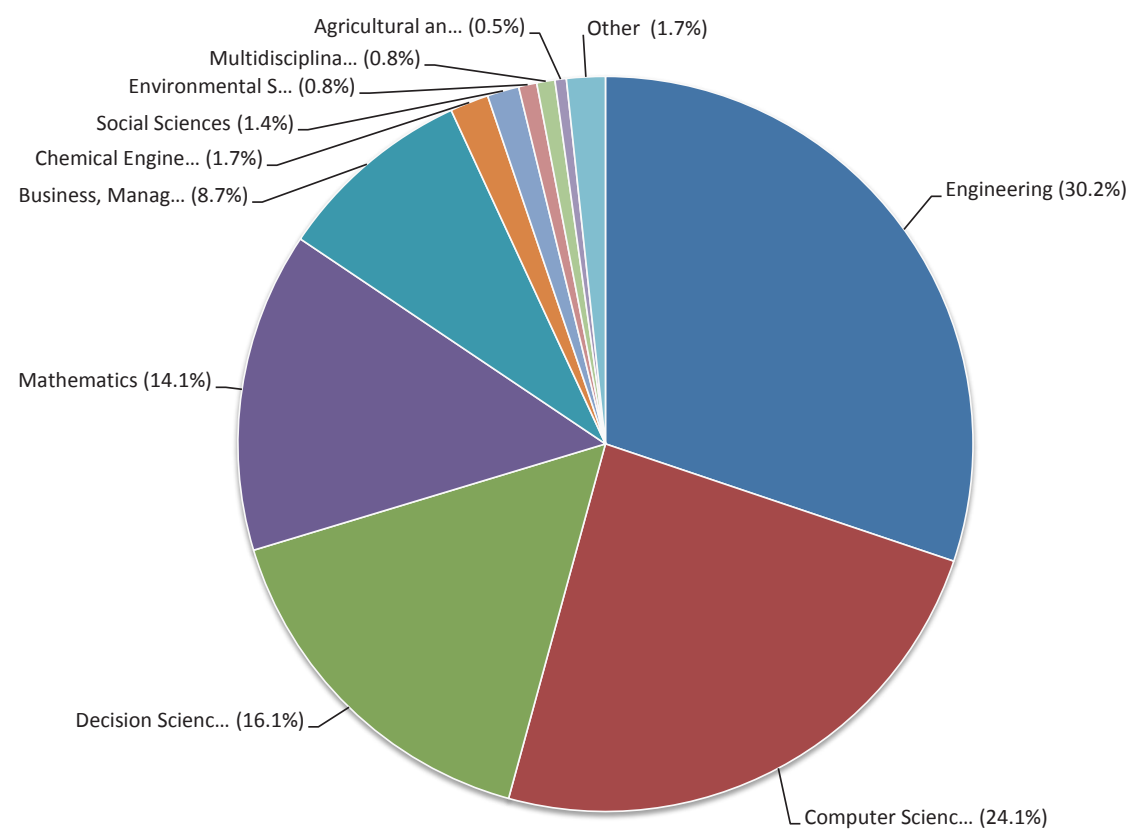

Fig. 2. Most popular subject areas of articles indexed in Scopus database referring to the layout optimisation

Source: elaborated by the authors based on (http://bazy.pb.edu.pl).

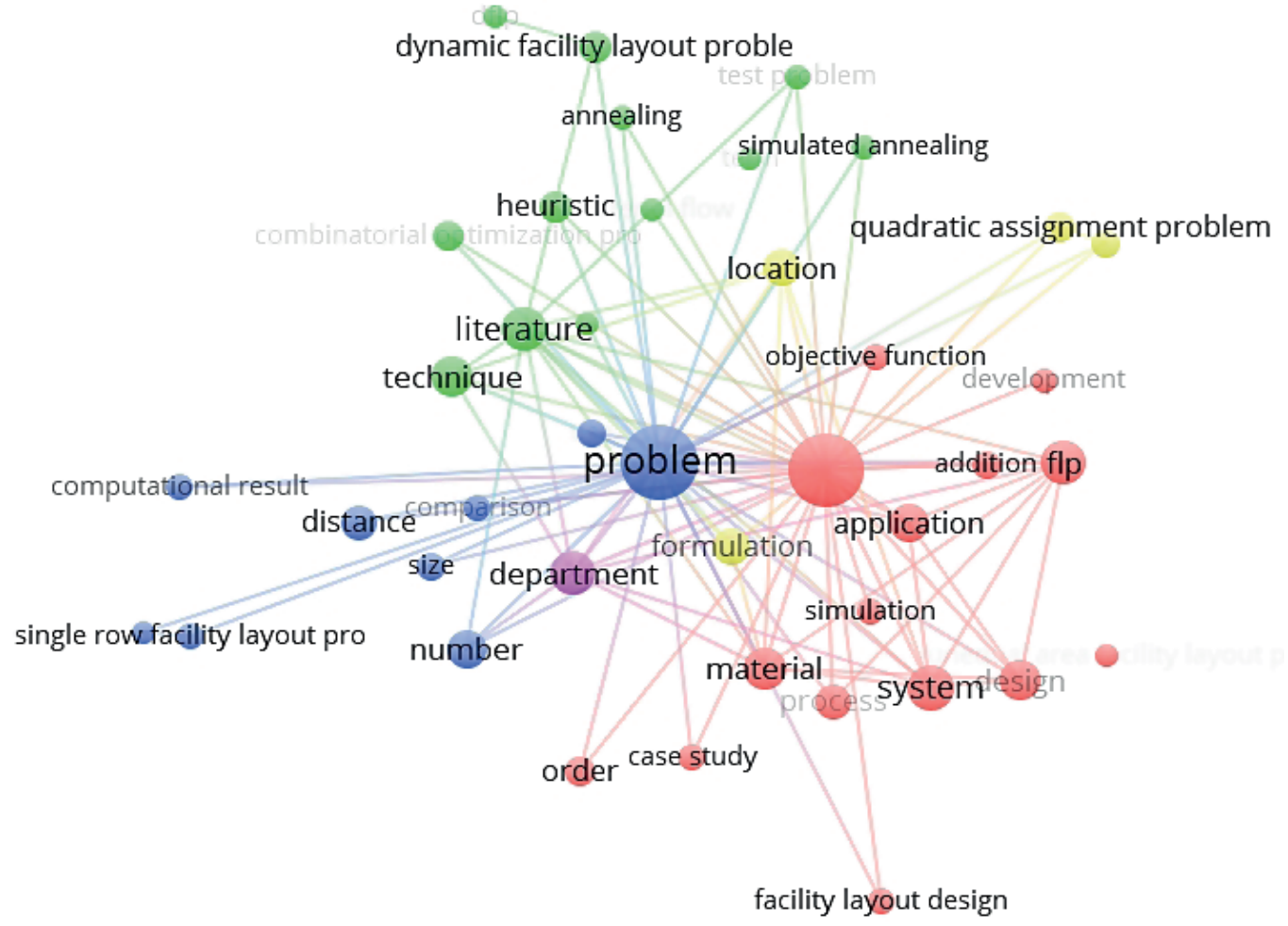

Fig. 3. Map of co-occurrence with research areas related to the scope of the facility layout optimisation problem from Scopus database in 2012-2017

Source: elaborated by the authors based on (http://bazy.pb.edu.pl) with the use of the VoSviewer software. 
tioned earlier related to the design and operation of production lines.

Optimisation methods for production processes are, considered an important tool for continuous improvement of product quality (Radziszewski et al., 2016). They include the modelling of input and output parameters and the determination of optimal conditions (Mukherjee \& Pradip, 2006). There are many ways to optimise the placement of workstations. For example, Santarek and Lis distinguished 86 methods (Lis \& Santarek, 1980). They selected four criteria for the classification of the methods, namely, the accuracy of obtained solutions, the manner in which positions were set up, the type of placement received, and the form of the presentation of the setup positions. The mentioned classifications included numerical parameters of the method and their operational properties and did not consider the characteristics of the manufacturing process. Methods for workstation layout optimisation are constantly modified and developed. Among the currently available methods used to optimise the deployment of workstations, the following can be distinguished (Sa'udach et al., 2015; Aydinel et al., 2008; Khan, 2004; Burduk et al., 2016; Wu et al., 2007; Mahdavi et al., 2009; Zielecki et al., 2014; Kowalski et al., 2016; Ojaghi et al., 2015; Ertay et al., 2006; Abdinnour-Helm et al., 2000; Hassan et al., 1986):

- mathematical methods,

- CORELAP,

- Schmidgall's triangles,

- Systematic Layout Planning (SLP),

- COFAD,

- BLOCPLAN,

- SHAPE algorithm,

- Graph-Based Theory (GBT),

- strategies for minimising transport costs,

- CRAFT,

- ALDEP,

- LAYOPT.

Existing methods for the optimisation of workstation can be divided into strict and approximate methods, of which strict methods can be applied only in the case of the limited choice of the workspace (Santarek, 1987). The wider application of methods occurs in the case of approximate methods, among which one can distinguish methods with limited and unlimited possibility to choose places.

The large number and variety of available optimisation methods may generate difficulties related to the choice of the appropriate method depending on the type and characteristics of the manufacturing process (Halicka et al., 2015). It is necessary to create a solution supporting the selection of an appropriate method to optimise the deployment of workstations, enabling the improvement of manufacturing processes. Also, despite the diversity and a large number of methods used to optimise the distribution of workstations, there are often no clear rules related to them.

An important factor is the limitations and strengths of the methods used for the optimisation of facility layout, which have been presented in the literature, as well as the appropriate indication of problems that can be solved with their help. Main features of production lines that are important in determining the best optimisation method are as follow (Rekiek et al., 2002):

- topology of the manufacturing process,

- designation of available equipment,

- connections between devices,

- method and location of stock storage,

- material transfer - the determination of transport routes,

- lot size,

- batch processing time,

- number of working shifts,

- resource constraints,

- time limits,

- costs.

It should also be noted that other methods are used when reorganising and designing new production lines (Lis \& Santarek, 1980). The set of methods used to optimise the distribution of positions within a production line is the basis for developing a solution to support the design of production lines. Selected optimisation methods were used to develop the original methodology for the design of the optimal distribution of workstations, which would allow accelerating the design of new or the improvement of existing production processes.

\section{PROPOSAL OF AN ORIGINAL METHODOLOGY FOR THE FACILITY LAYOUT DESIGN}

Available studies indicate that many production companies have little knowledge in the field of planning and production control, and optimisation methods are used rarely or not at all. The theory and methods for solving optimisation problems are either 
unknown or improperly understood by practitioners (Siderska \& Jadaan, 2018). Another indicated problem is the belief that theoretical situations are not sufficiently similar to those found in practice (Rekiek et al., 2002). The reason for this situation may be the lack of a comprehensive look at the problem related to choosing of the right method for the optimisation of the workstation deployment and the lack of a tool to support the selection and the use of the optimisation method to solve a specific problem.

The methodologies used to optimise the facility layout have some limitations (related to failure to adapt to current trends in the design of manufacturing processes, among other things, and a decision problem related to the selection and application of appropriate optimisation methods to specific features of the manufacturing process); consequently, they must be further developed.

The literature review revealed a methodology for designing the arrangement of objects based on the Systematic Layout Planning. However, it has a number of limitations, the most important of which is narrowing down the research to the use of one approach in the deployment of workstations (Yang et al., 2000).

Lis and Santarek (1980) prepared a general scheme of the methodology for designing the deployment of workstations based on the operational research strategy. The authors stated that the indicated scheme could be used in the design of new production cells or the remodelling of existing ones, but they did not indicate differences between the two. The proposed methodology scheme consists of five main stages, namely, the formulation of project task, the construction of a mathematical model, the solution of the task, model adjustments and solution evaluation, and project implementation. The discussed methodology does not specify the method for selecting the optimisation method depending on characteristics of the manufacturing process. The authors acknowledged a large number of available methods and indicated that their variety imposes to choose one. However, a particular method or a group of methods is not chosen dependent on the characteristics of the manufacturing process. Therefore, it is necessary to prepare a methodology that considers the knowledge about the type and characteristics of the manufacturing process, the criterion of optimisation, limitations of the production process, and available methods of optimisation. The methodology should consist of a description of the stages, activities and activities used to clearly describe how to optimise the design of workstations. It should also include a set of methods that can be applied depending on the specific characteristics of manufacturing processes.

The initial research assumed that the original design methodology (Fig. 4) would consist of two blocks: a part supporting the design of a new layout of workstations and a part dedicated to the reconstruction of the existing layout of the stands.

From the standpoint of a factory, studies are desirable regarding non-interference with the operation of the production line (Pałucha, 2011). The problem of the deployment of workstations can be modelled using various types of tools, including spatial, structural and mathematical models (JakowskaSuwalska \& Wolny, 2009). Currently, digital models depicting the existing infrastructure are a popular tool used in the optimisation of manufacturing processes and the positioning of workstations within production lines (Ryan \& Heavey, 2006; Matuszek \& Kurczyk, 2017). Planning research based on simulation models can greatly contribute to the development of efficient production lines. Research that does not interfere with the work of the manufacturing process requires the development of a methodology that considers the use of a model simulating the operation of production lines and containing process parameters. A correctly constructed simulation model allows predicting the effects of changes and the choice of the optimal decision variant.

In the part supporting the design of a new workplace layouts, key elements are gathering and analysing the parameters of the projected placement (identifying the number of positions and establishing connections between positions) and choosing the method for optimising the distribution of positions are using which the layout of the production line implemented in the digital model would be designed (phase I). The next steps are the analysis of the developed model and the comparison of the results obtained and the selection of the best solution (phase II).

The second part (reorganisation of the facility layout) consists of four main stages containing elements of the digital model structure pertaining to the tested object, the diagnostics and optimisation phase, and the evaluation of the obtained results:

- construction phase (I) - containing the examination of the current configuration of workstations and the construction of the model;

- diagnostic phase (II) - including the analysis of the simulation model (measuring the effective- 
Designing a new manufacturing process

Designing a new facility layout

$------------------------$

Analysis of the parameters of the manufacturing process

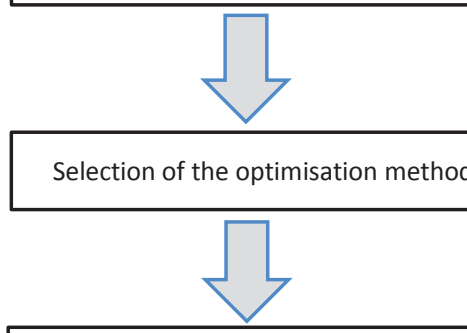

Development of a facility layout project

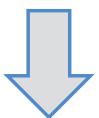

Preparation of the design of the manufacturing process in the digital model

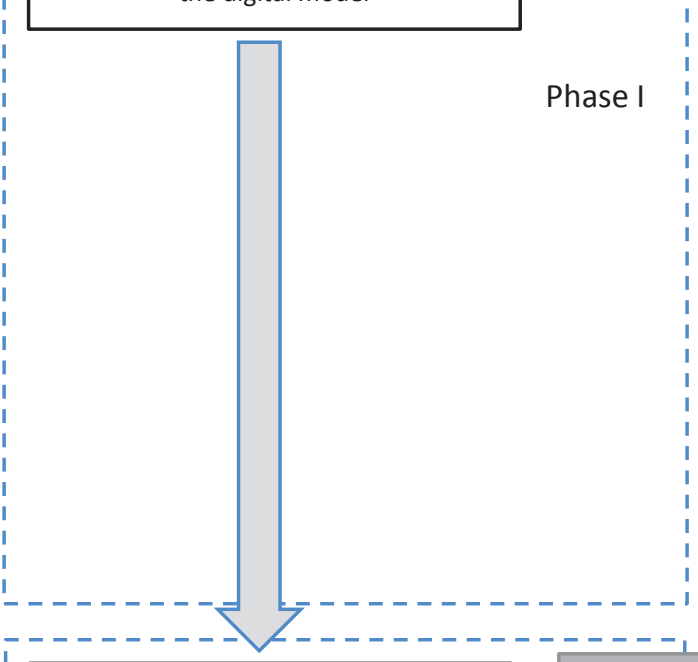

Analysis of the digital model

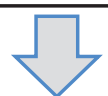

Comparison of the available variants

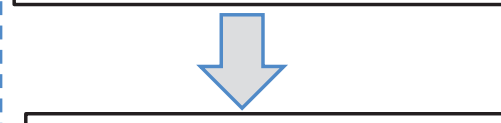

Phase II

Choosing the best solution

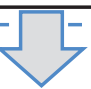

Reorganisation of the production process

Reorganisation of the facility layout

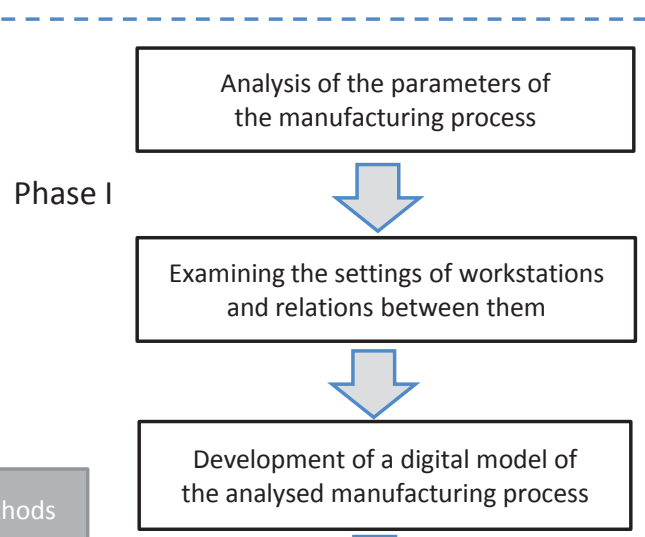

the analysed manufacturing process

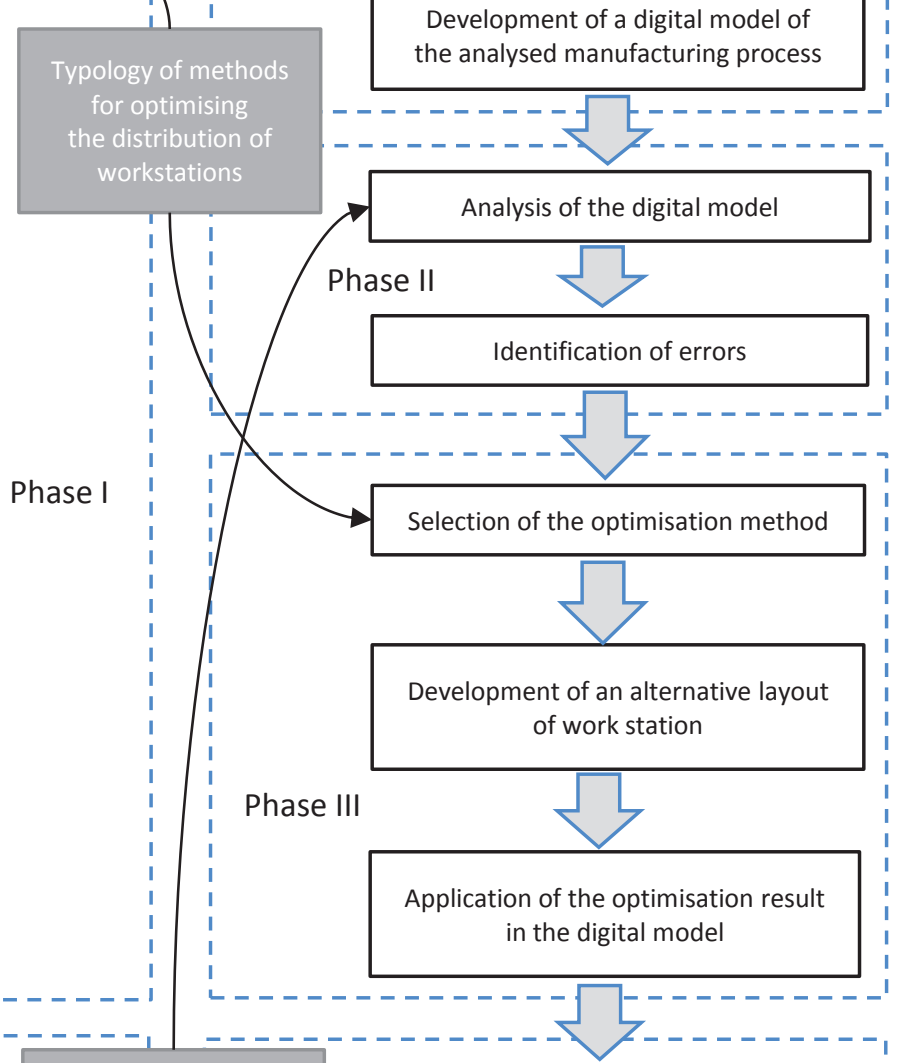

in the digital model
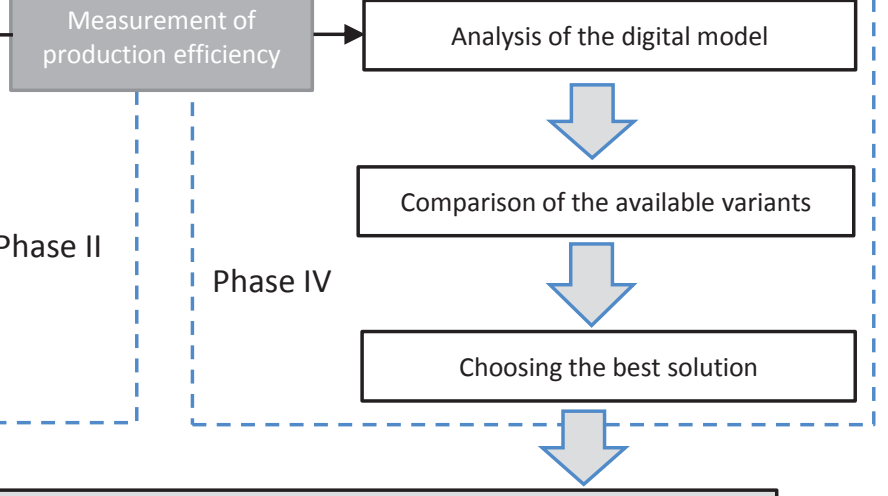

Implementation of results

Fig. 4. Proposed preliminary diagram of the methodology for designing the optimal placement of workplaces 
ness according to the index chosen by the designer while the indicators help in making decisions and conducting activities aimed at better and more efficient functioning of the production line) and identification of weaknesses (bottlenecks) of the production process;

- optimisation phase (III) - consisting of the selection of methods for optimising the deployment of workstations, developing an alternative solution and introducing results in a simulation model;

- control phase (IV) - comparison of the results obtained and selection of the best solution (if several are available).

The general diagram showing the elements of the methodology identified during the previous research is presented in Fig. 4. In the course of the research, the methodology will be detailed, and the relationships between particular elements will be analysed at a greater depth. It is also not possible to exclude the distinction or deletion of certain elements.

As mentioned before, there are many ways to optimise a facility layout, but there is no clear procedure for choosing methods that allow optimal placement of workstations. Therefore, the key element of designing the optimal distribution of workstations will be the original typology of methods for optimising the distribution of workstations, which, among other things, will consider the following: the type and characteristics of the manufacturing process, factors affecting the shape of the production line, and an optimisation criterion. The proposed typology will allow the selection of the best method for the optimisation of the distribution of workstations depending on characteristics of the manufacturing process. Choosing the right method will be a multi-stage task:

- phase I: defining the type of the designed production line;

- phase II: determining factors affecting the distribution of workstations;

- phase III: determining the optimisation criterion;

- phase IV: selecting the method for the optimisation of the deployment of workstations depending on the characteristics of the manufacturing process.

A multi-stage selection of the method used in the design or optimisation of production lines will allow narrowing down the choice of methods from the available number before the implementation in the simulation model.

\section{CONCLUSIONS}

The continuous need to effectively respond to competition and the growing pressure made by customers on product quality demands for the use of optimisation methods in production processes are fundamentally important for the production unit.

Problems related to planning and placement of production positions are not a new topic in the academic circles as these issues have been the subject of scientific research in response to constantly increasing competition between enterprises. The pressure to improve the technological processes of enterprises and competition in the market is also reflected in scientific research centred around production. A literature review on methods for the optimisation of workplaces indicated a constant and growing interest in the analysed topic. A review of publications in Scopus database was made with the aim to identify methods for optimising the facility layout and examine the dynamics of changes in the number of publications on the subject in question in $1975-2017$. Research efforts related to methods used to optimise production processes have intensified in recent years. The analysis and use of optimisation methods, as well as the introduction of methods and the creation of new algorithms, is a constant research challenge.

Designing the deployment of workstations requires a two-pronged approach, namely, focusing on the design of new production lines and the reorganisation of existing systems. The literature review also unveiled a close relationship between scheduling and scheduling production tasks, and the facility layout designing. Available optimisation methods focus on improving selected process features. From the point of view of a production line technologist, it is crucial to choose a method or a set of methods with the greatest possible amount of available data.

Optimisation methods help to create a workstation layout scheme that allows the design of facility layout, including distances between machines, machine distances from transport routes or construction elements of production halls. An important condition for obtaining the intended effects is proper identification and quantification of emerging problems, as well as an appropriate selection of methods and tools leading to their solution.

The article is an introduction to further work related to the identification and classification of methods for optimising the distribution of workstations. The set of optimisation methods and tools was 
created as the basis for a further search for instruments to improve production processes and a base for in-depth research related to the optimisation of production processes. Focusing on the use of the chosen method, basic methods were indicated for the optimisation of production lines and the introduction to the original methodology.

Further research will include, inter alia, the development of the authors' typology of methods for optimising the distribution of workstations, considering the characteristics of the manufacturing process and optimisation criteria, as well as the verification of the authors' methodology for designing the optimal facility layout.

\section{LITERATURE}

Abdinnour-Helm, S., \& Hadley, S. W. (2000). Tabu search based heuristics for multi-floor facility layout. International Journal of Production Research, 38(2), 365-383.

Aydinel, M., Sowlati, T., Cerda, X., Cope, E., \& Gerschman, M. (2008). Optimization of production allocation and transportation of customer orders for a leading forest products company. Mathematical and Computer Modelling, 48(7), 1158-1169.

Azadivar, F., \& Wang, J. (2000). Facility layout optimization using simulation and genetic algorithms. International Journal of Production Research, 38(17), 4369-4383.

Brundage, M. P., Chang, Q., Li, Y., Arinez, J., \& Xiao, G. (2016). Sustainable manufacturing performance indicators for a serial production line. IEEE Transactions on Automation Science and Engineering, 13(2), 676-687.

Burduk, A., \& Górnicka, D. (2016). Usprawnienie przepływu materiałów i rozmieszczenia stanowisk produkcyjnych na przykładzie małego przedsiębiorstwa produkcyjnego [Improving material flow and deployment of production stations on the example of a small manufacturing company]. Gospodarka Materiałowa i Logistyka, 6, 23-43.

Ertay, T., Ruan, D., \& Tuzkaya, U. R. (2006). Integrating data envelopment analysis and analytic hierarchy for the facility layout design in manufacturing systems. Information Sciences, 176(3), 237-262.

Friedrich, C., Klausnitzer, A., \& Lasch, R. (2018). Integrated slicing tree approach for solving the facility layout problem with input and output locations based on contour distance. European Journal of Operational Research, 270(3), 837-851.

Gálová, K., Rajnoha, R., \& Ondra, P. (2018). The use of industrial lean management methods in the economics practice: An empirical study of the production companies in the Czech Republic. Polish Journal of Management Studies, 17, 93-104.
Godinho Filho, M., Devos Ganga, G. M., \& Gunasekaran, A. (2016). Lean manufacturing in Brazilian small and medium enterprises: implementation and effect on performance. International Journal of Production Research, 54(24), 7523-7545.

Halicka, K. (2016a). Innovative Classification of Methods of The Future-Oriented Technology Analysis. Technological and Economic Development of Economy, 22(4), 574-597. doi:10.3846/20294913.2016.1197164

Halicka, K. (2016b). Prospektywna analiza technologii metodologia i procedury badawcze [Prospective technology analysis - research methodology and procedures]. Białystok, Poland: Oficyna Wydawnicza Politechniki Białostockiej.

Halicka, K., Lombardi, P. A., \& Styczyński, Z. (2015). Future-oriented analysis of battery technologies. Proceedings of the IEEE International Conference on Industrial Technolog, 2, 1019-1024.

Hassan, M. M. D., Hogg, G. L, \& Smith, D. R. (1986). SHAPE: a construction algorithm for area placement evaluation. International Journal of Production Research, 24(5), 1283-1295.

Hu, S. J., Ko, J., Weyand, L., El Maraghy, H. A., Lien, T. K., Koren, Y., \& Shpitalni, M. (2011). Assembly system design and operations for product variety. CIRP Annals-Manufacturing Technology, 60(2), 715-733.

Jakowska-Suwalska, K., \& Wolny, M. (2009). Problem rozmieszczenia stanowisk roboczych jako wielokryterialny problem decyzyjny [The problem of the distribution of workstations as a multi-criteria decision problem]. Organizacja i Zarządzanie, 49, 1-10.

John, B., \& Jenson, J. E. (2013). Analysis and simulation of factory layout using ARENA. International Journal of Scientific and Research Publications, 3(2), 1-8.

Khan, M. A. (2014). Transportation Cost Optimization Using Linear Programming. International Conference on Mechanical, Industrial and Energy Engineering. Khulna, Bangladesh.

Kikolski, M. (2018). Reorganizacja układu hali produkcyjnej za pomocą metody SLP [Reorganization of the production hall layout using the SLP method]. In R. Knosala (Ed.), Innowacje w zarzadzaniu i inżynierii produkcji. Tom II [Innovations in management and production engineering. Volume II], (pp. 536-544). Opole, Poland: Oficyna Wydawnicza Polskiego Towarzystwa Zarządzania Produkcją.

Koliński, A., \& Tomkowiak, A. (2010). Wykorzystanie koncepcji analizy wąskich gardeł w zarządzaniu produkcja [The use of the concept of bottlenecks analysis in production management]. Gospodarka Materiałowa i Logistyka, 9, 16-21.

Kosieradzka, A. (Ed.). (2008). Podstawy zarzadzania produkcja [Basics of production management]. Warszawa, Poland: Oficyna Wydawnicza Politechniki Warszawskiej.

Kowalski, A., \& Lesień, A. (2016). Organizacja procesów wytwórczych krążników przenośników taśmowych [Organization of manufacturing processes of conveyor belt conveyors]. Innowacje $w$ Zarządzaniu i Inżynierii Produkcji, 1(5), 730-739. 
Lis, S., \& Santarek, K. (1980). Projektowanie rozmieszczenia stanowisk roboczych [Designing the deployment of workstations]. Warszawa, Poland: PWN.

Mahdavi, I., Paydar, M. M., Solimanpur, M., \& Heidarzade, A. (2009). Genetic algorithm approach for solving a cell formation problem in cellular manufacturing. Expert Systems with Applications, 36(3), 6598-6604.

Matuszek, J., \& Kurczyk, D. (2017). Projektowanie procesów i systemów produkcyjnych z wykorzystaniem technologii komputerowej wirtualizacji [Designing processes and production systems using computer virtualization technology]. Innowacje $w$ zarzadzaniu i inżynierii produkcji, 2(12), 741-752.

Mukherjee, I., \& Pradip, K. R. (2006). A review of optimization techniques in metal cutting processes. Computers \& Industrial Engineering, 50(1), 15-34.

Ojaghi, Y., Khademi, A., Yusof, N. M., Renani, N. G., \& bin Syed Hassan, S. A. H. (2015). Production layout optimization for small and medium scale food industry. Procedia CIRP, 26, 247-251.

Pałucha, K. (2011). Wybrane problemy uruchamiania nowej produkcji [Selected problems of starting a new production]. Organizacja i Zarządzanie, 56, 215-237.

Piskrzyńska, K., \& Cieślar, S. (2015). The Efficiency in Microenterprises Versus the Organization of Working Time. Forum Scientiae Oeconomia, 3(4), 79-89.

Radziszewski, P., Nazarko, J., Vilutiene, T., Dębkowska, K., Ejdys, J., Gudanowska, A., Halicka, K., Kilon, J., Kononiuk, A., Kowalski, K. J., Król, J. B., Nazarko, Ł., \& Sarnowski, M. (2016). Future Trends in Road Technologies Development in the Context of Environmental Protection. Baltic Journal of Road and Bridge Engineering, 11(2), 160-168. doi:10.3846/ bjrbe.2016.19

Rekiek, B., Dolgui, A., Delchambre, A., \& Bratcu, A. (2002). State of art of optimization methods for assembly line design. Annual Reviews in Control, 26(2), 163-174.

Ryan, J., \& Heavey, C. (2006). Process modeling for simulation. Computers in Industry, 57, 437-450.

Sa'udah, N., Amit, N., \& Ali, M. N. (2015). Facility Layout for SME Food Industry via Value Stream Mapping and Simulation. Procedia Economics and Finance, 31, 797-802.

Santarek, K. (1987). Podstawy metodyczne projektowania rozmieszczenia komórek produkcyjnych [Methodological basis for designing the distribution of production cells]. Warszawa, Poland: Państwowe Wydawnictwo Naukowe.

Siderska, J., \& Jadaan, K. S. (2018). Cloud manufacturing: a service-oriented manufacturing paradigm. A review paper. Engineering Management in Production and Services, 10(1), 22-31.

Staniewska, E. (2015). Doskonalenie procesu produkcyjnego przedsiębiorstwa hutniczego [Improvement of the metallurgical enterprise production proces]. Logistyka, 2, 720-727.

Teunter, R., Kaparis, K., \& Tang, O. (2008). Multi-product economic lot scheduling problem with separate production lines for manufacturing and remanufacturing. European Journal of Operational Research, 191(3), 1241-1253.
Vergara, H. A., \& Kim, D. S. (2009). A new method for the placement of buffers in serial production lines. International Journal of Production Research, 47(16), 4437-4456.

Wolniak, R. (2013). Metody i narzędzia Lean Production i ich rola w kształtowaniu innowacji w przemyśle [Lean Production methods and tools and their role in shaping innovations in industry]. Innowacje w zarządzaniu i inżynierii produkcji, 1(3), 49-58.

Wu, X., Chu, C. H., Wang, Y., \& Yan, W. (2007). A genetic algorithm for cellular manufacturing design and layout. European journal of operational research, 181(1), 156-167.

Yang, T., Su, C. T., \& Hsu, Y. R. (2000). Systematic layout planning: a study on semiconductor wafer fabrication facilities. International Journal of Operations \& Production Management, 20(11), 1359-1371.

Zawadzka, L. (2007). Współczesne problemy i kierunki rozwoju elastycznych systemów produkcyjnych [Contemporary problems and directions of development of flexible production systems]. Gdańsk, Poland: Wydawnictwo Politechniki Gdańskiej.

Zielecki, W., \& Sęp, J. (2014). Wspomaganie projektowania linii produkcyjnych U-kształtnych metodą programowania sieciowego [Supporting the design of U-shaped production lines using the network programming method]. Innowacje $w$ Zarządzaniu i Inżynierii Produkcji, 1(4), 682-688.

Zwierzyński, P. (2018). Seru production jako japońska forma produkcji komórkowej [Seru production as a Japanese form of cell production]. In R. Knosala (Ed.), Innowacje w zarządzaniu i inżynierii produkcji. Tom I [Innovations in management and production engineering. Volume I], (pp. 530-537). Opole, Poland: Oficyna Wydawnicza Polskiego Towarzystwa Zarządzania Produkcją. 